
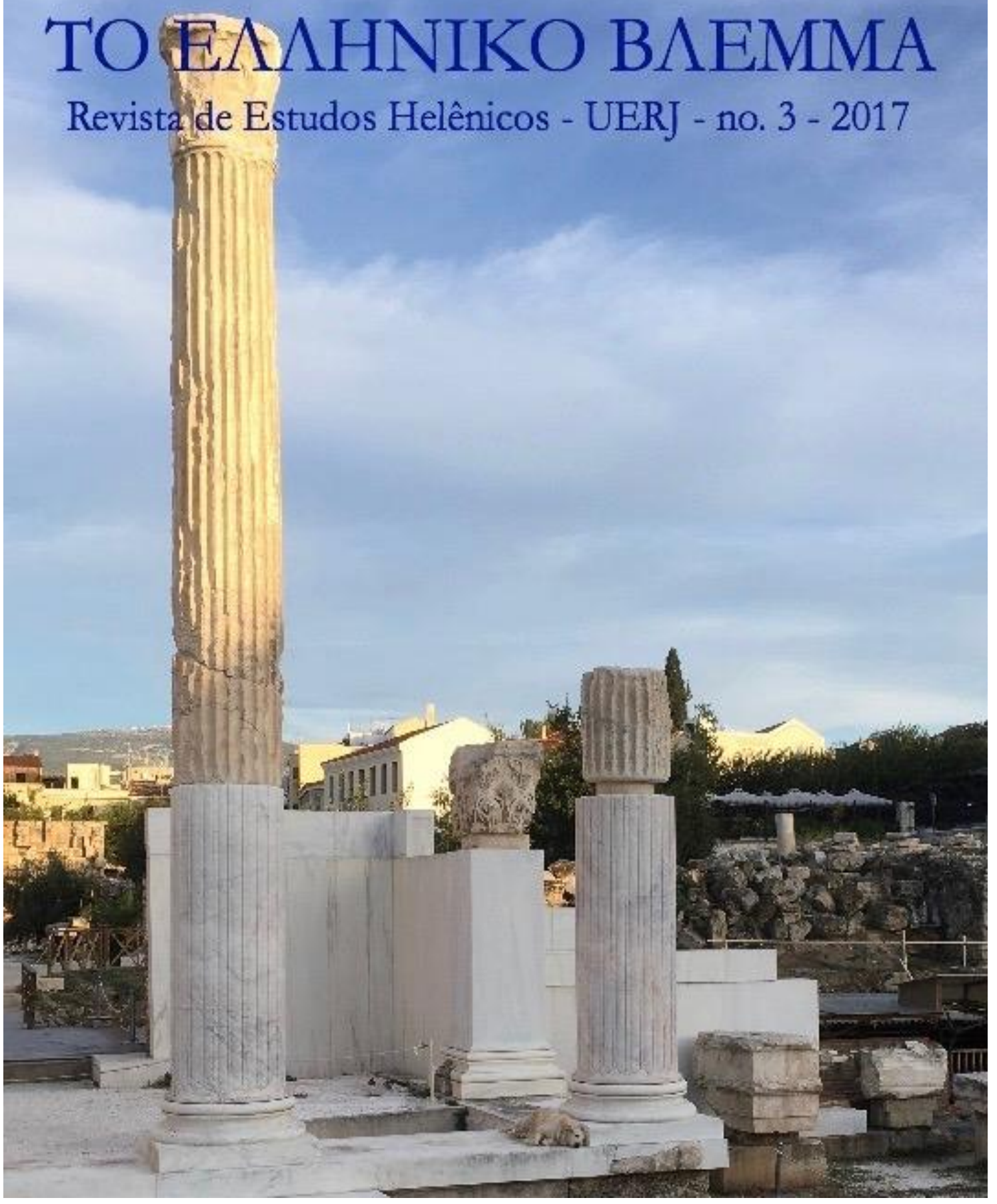


\title{
AFINAL, O QUE É TRAGÉDIA?
}

\author{
Alexandra Marla Marques da Rocha - UniRitter
}

\section{Resumo}

Percebe-se que o tempo dá conta de fazer mudanças não só em nós, seres de linguagem, mas também, e por extensão, no sentido das palavras. Tragédia, por exemplo, palavra que vem do grego traigoidia, pelo latim tragoedia, adquiriu grafias distintas como já se observa, mas também sentido diverso ao longo do tempo. Antes, porém, da referida análise, seria o caso de verificar o conceito de tragédia que tem início com os tragediógrafos gregos e assume variações de sentido até a contemporaneidade. Para observar tal alteração, faz-se necessário revisitar o passado, especificamente, a antiga Grécia, uma vez que lá foi o berço desse gênero literário. É certo que, mais afastado ou semelhante em seu sentido ao que os gregos atribuiam ao termo, a palavra "tragédia" perdura ainda hoje em temas de romances, dramas, contos, poesias. Utilizado em notícias para qualificar acidentes e catástrofes, o termo também compõe o vocabulário da vida doméstica, atribuído a desafortunados e às vezes simples acontecimentos do dia a dia. O terror e a piedade que sentimos, hoje, diante de acontecimentos inesperados, a que chamamos de tragédias, evidencia, que os homens mantêm em sua história, desde o princípio de sua existência, sentimentos que afloram de modo similar. Para discorrer sobre a origem da tragédia grega, consultamos os autores: Jacqueline de Romilly (1997), Albin Lesky (1990) e o indispensável estagirita Aristóteles. Quanto à tragédia moderna nos pautaremos nas reflexões de Williams (2002), Machado (2006) e Serra (2006).

Palavras-chave: tragédia grega, tragediógrafos, tragédia moderna

\section{Resumen}

Se percibe que el tiempo se ocupa de hacer cambios no solo en nosotros, seres de lenguaje, sino también, y por extensión, en el sentido de las palabras. Tragedia, por ejemplo, palabra que viene del griego traigoidia, por el latín tragoedia, adquirió grafias distintas como ya se observa, pero también un sentido diferente a lo largo del tiempo. Antes, sin embargo, del referido análisis, sería el caso de verificar el concepto de tragedia que tiene inicio con los tragediógrafos griegos y asume variaciones de sentido hasta la contemporaneidad. Para observar tal modificación, se hace necesario revisitar el pasado, específicamente, la antigua Grecia, una vez que allí fue la cuna de este género literario. Es cierto que, más alejado o semejante en su sentido a lo que los griegos atribuían al término, la palabra "tragedia" perdura aún hoy en temas de 
romances, dramas, cuentos, poesias. Utilizado en noticias para calificar accidentes y catástrofes, el término también compone el vocabulario de la vida doméstica, atribuido a desafortunados y a veces a simples acontecimientos del día a día. El terror y la piedad que sentimos, hoy, ante acontecimientos inesperados, a los que llamamos tragedias, evidencia, que los hombres mantienen en su historia, desde el principio de su existencia, sentimientos que afloran de modo similar. Para discurrir sobre el origen de la tragedia griega, consultamos a los autores: Jacqueline de Romilly (1997), Albin Lesky (1990) y el indispensable estagirita Aristóteles. Con respecto a la tragedia moderna nos pautaremos en las reflexiones de Williams (2002), Machado (2006) y Serra (2006).

Palavras Clave: tragedia griega, tragediógrafos, tragedia moderna

\section{A origem da Tragédia}

\section{Uma leitura da Tragédia segundo Jacqueline de Romilly}

O brilho da tragédia grega se prende com a amplitude da sua significação, com a riqueza do pensamento que os autores deram a esse gênero literário graças a uma linguagem acessivel que emana da emoção, provocando assim uma reflexão sobre o homem. É, sem dúvida, por esse motivo que em todas as épocas de crise, como na virada do século XXI, sente-se a necessidade de refletir sobre essa forma inicial de gênero.

A tragédia grega perdurou por oitenta anos, período concomitante ao momento do desenvolvimento político de Atenas. Conta-nos, a história dos atenienses, que a primeira tragédia ocorreu junto com a grande vitória alcançada por Atenas sobre os invasores persas, especificamente a grande Vitória de Salamina ${ }^{1}$ em 480 a.C. Essa primeira tragédia conservada é de 472 a.C trata dos Persas, de Ésquilo. Coincidentemente, ao cessar a grande batalha em Atenas, cessou também a própria vida da tragédia, ou seja, quando falamos, hoje, de tragédia grega, baseamo-nos quase completamente nas obras conservadas dos três autores: Sófocles, Euripedes, Ésquilo

Constata-se que o nascimento da tragédia grega é incerto, porém, sabe-se que possui uma origem religiosa que depende do culto a Dioniso, visto que só nas festas desse deus é que se representavam as tragédias, isto é, a grande ocasião ocorria, na época Clássica, nas festas das Dionisíacas urbanas, celebradas na Primavera, mas também havia concursos de tragédias nas festas Lenéias ${ }^{2}$, que ocorriam por volta do

\footnotetext{
1 Batalha de Salamina: "combate entre a frota persa e a grega no ano 480 a.C. No século V a.C., gregos e persas se envolveram em uma série de conflitos que, em grande parte, foram causados pela tentativa de cada lado de conquistar a região da Jônia, na Ásia Menor. Mileto, que era uma colônia grega na Jônia, tentou se livrar do domínio persa e forneceu o estopim para o início dos conflitos. Esses embates ficaram conhecidos como Guerras Médicas e ocorreram em dois momentos". (WEIR, 2010, p.10)

2 Leneias - Era um festival Ateniense dedicado ao deus Dioniso, era celebrado durante o inverno, por volta do mês Gamélion (janeiro). Consistia, em sacrificios e em concursos dramáticos de tragédias e de comédias. Limitavam-se aos cidadãos atenienses. Durante o festival das Lenéias, eram apresentadas peças de teatro e comédias, era um empreendimento público, organizado pelos magistrados mais importantes da cidade e terminava numa assembleia onde todos os cidadãos podiam participar. Era avaliado o desempenho dos organizadores, e de todos os concorrentes. O festival decorria nos moldes da prática politica e democracia Ateniense. (GASSNER, 1974, p.29)
} 
mês de janeiro. A própria representação inseria-se num conjunto eminentemente religioso, acompanhada de sacrificios e procissões.

O nascimento da tragédia está associado, portanto, à existência da tirania, ou seja, de um regime forte que se apoiava no povo contra a aristocracia. Diferente dos nossos espetáculos cênicos atuais, compostos de várias apresentações que se repetem ao longo das semanas, meses e até anos, havia, para os gregos, duas festas anuais onde se apresentavam tragédias. Cada festa comportava um concurso, que durava três dias; e, em cada dia, um autor era designado com muita antecedência para representar três tragédias seguidas. A representação era prevista e organizada às expensas do Estado. Somente um dos altos magistrados da cidade podia escolher os poetas, e escolher também os cidadãos ricos que arcariam com as despesas do evento. No dia da representação, o povo era convidado a presenciar o espetáculo. Desde a época de Péricles ${ }^{3}$ os cidadãos pobres podiam ir à representação das peças; para isso, recebiam um abono. Com os cidadãos (ricos e pobres) presentes, o espetáculo revestia-se de caráter nacional, portanto, solene. (ROMILLY, 1997, p.15).

Por se tratar de um gênero literário, faz-se necessário entendermos o que significa o termo tragédia - a trag-oedia significa 'o canto do bode'. Mas que relação há entre o canto do bode com a tragédia? Segundo Jacqueline de Romilly em $A$ Tragédia grega $(1997$, p. 15) a hipótese mais difundida consiste em aproximar o bode dos sátiros, que, normalmente, estão associados ao culto a Dioniso. Argumenta também, baseada em Aristóteles (Poética, 1449 a 11) que a tragédia teve uma origem bastante próxima a da comédia - grupos de fiéis a Dioniso, representando sátiros cujo aspecto ou vestuário fazia pensar no bode.

Nessa hipótese, segundo a autora, há duas dificuldades: a primeira é de ordem técnica, pois os sátiros não foram associados a bodes; a segunda constata que termos e atos lascivos não comportavam o mote da tragédia. O culto a Dioniso parece mais associado às corças e às suas crias do que ao bode. A autora argumenta que o canto dos bodes seria muito mais a do drama satírico do que a da tragédia, pois os cantos lascivos de sátiros não pertenciam à tragédia, a qual não era de todo lasciva nem comportava qualquer traço de sátiros. Em seus estudos a autora parece dar uma conclusão para esse dilema:

É por isto que, desde a Antiguidade, alguns preferiram interpretar de outra forma o nome da tragédia. Pensaram que o bode era ou a recompensa oferecida ao melhor praticante, ou a vítima oferecida em sacrificio. [...] Neste caso, o ditirambo 4 teria servido apenas de modelo formal, simultaneamente à tragédia e ao drama satírico, que constituíram dois gêneros paralelos, mas de inspiração totalmente distinta. Esta interpretação tem o

\footnotetext{
${ }^{3}$ Péricles - é um dos mais ilustres atenienses. Ele se destaca durante o período de hegemonia de Atenas. O governo de Péricles foi responsável por ampla modernização, ampliação dos vínculos comerciais, enriquecimento e disseminação dos padrões políticos de Atenas. Tamanho foi o impacto do governante que o século V a.C. ficou conhecido como "Século de Péricles". (SOUZA, 1974, p. 95-96)

4 Ditirambo: latim dithyrambu; grego dithyrambos- vocábulo de incerta etimologia. Primitivamente (por volta do século VII a.C.). O ditirambo consistia num canto em louvor a Baco, e aludiria, pelo significado estrito de "duas portas", ao duplo nascimento do deus do vinho e do prazer. (dis, duas vezes; thyra, porta, ambainein, passar). Segundo a mitologia grega, Baco ou Dioniso (como era chamado pelos gregos) teria sido gerado de um seio de Semele e, posteriormente, da coxa de Zeus. Alguns estudiosos advogam também a etimologia Dithyrambos, apelativo de um sátiro pertencente ao séquito de Baco, ao passo que outros recorrem a thriambos, hino triunfal, pelo latim triumphu(m) vinculado, pois, aos cultos dionisiacos e exaltando os prazeres da mesa, o ditirambo estaria, segundo Aristóteles (Poética, IV, 1449a), na raiz da Tragédia. O poeta Arion, de Corinto, é considerado o primeiro a compor ditirambos com título próprio e ação homogênea. (MOISES, 1974, p.157-158)
} 
grande mérito de respeitar a diferença entre dois gêneros e de conduzir diretamente àquilo que constitui a originalidade intrínseca do gênero trágico. (ROMILLY, 1997, p.18).

Romilly enfatiza que o nascimento da tragédia permanece como um acontecimento único, pois não há equivalente em nenhum outro país e em nenhuma outra época, tanto que as tragédias conservadas não mostram bodes nem sátiros, o que nos dá a entender que o tema desse gênero não vem desses cultos, tampouco de divertimentos. Mas é possivel que pessoas mascaradas tenham imitado alguma ação mítica situada fora do tempo. O que pode ter sido feito em um dia mais religioso. A tragédia pode ter aparecido apenas porque as festas em honra a Dioniso procuraram a essência das representações (ROMILLY, 1997, p.20).

A importância da tragédia estava no fato de o ator tornar pública uma emoção, uma explicação, um significado que não havia sido tratado antes. Um autor trágico retomava as representações e um outro, depois dele, regressava ao mesmo tema. Assim a originalidade dos autores não estava no nivel dos acontecimentos, da ação, do desenlace, mas no nível da interpretação pessoal. Eles construíram personagens e cenas capazes de comover. A questão era apresentar o sentimento da vida, inspirar terror e piedade, obrigar a partilhar um sofrimento ou uma ansiedade. (ROMILLY, 1997, p.22).

Os motes basilares da tragédia grega são de cunho religioso e político. A estrutura desse gênero divide-se em coro, personagens e ação. O ponto inicial da representação é o coro. Ele é considerado o elemento mais importante da tragédia, sua formação era feita pelos magistrados da cidade, que sabiamente escolhiam os cidadãos ricos, para que arcassem com as despesas que o evento traria. Esses magistrados tinham a honra de recrutar e de manter os quinze membros do coro ou coreutas. Há registros de que no início o coro era composto por cinquenta pessoas. Sófocles optou por quinze, depois foi reduzido para doze. O coro era indispensável por que representava pessoas intimamente interessadas no desenrolar da ação, seus cantos ocupavam um número considerável de versos. Em Ésquilo, muitos títulos das tragédias são atribuídos aos papéis confiados ao coro, como, por exemplo: Os Persas, as Suplicantes, as Coéforas e as Euménides (ROMILLY, 1997, p.28).

$\mathrm{Na}$ maioria das vezes, o coro era composto por mulheres ou anciãos demasiados velhos para combater ou para se defender, a exemplo dos anciãos do Agamêmnon, que já iniciam a peça com um lamento (ROMILLY, 1997, p.30).

Na tragédia Sete contra Tebas, o coro é constituído por mulheres da cidade que receiam o desastre da sua pátria. Elas sentem medo ao pensar no que as esperam, ou seja, medo de serem arrastadas - viúvas dos defensores "'ai! Jovens e velhas ao mesmo tempo - pelos cabelos, como cavalos... (versos 326 - 329)." (ROMILLY, 1997, p.29). Assim como o coro, as personagens também têm um papel importante na tragédia visto que enriquecem a análise psicológica do drama. Para isso, apresentam monólogos sobre o que pensam ou experimentam. Desse modo, diversificam e aumentam a atuação e a ressonância humana da peça. A fim de tornar o drama mais dinâmico, as personagens unidas iniciam na ação um movimento que lhe precipita o ritmo e renova o interesse de quem as assistem. (ROMILLY, 1997, p.40).

A pesquisadora revela que, no início, antes de Ésquilo, havia a presença de só um ator (possivelmente o narrador) face ao coro, o que era pouco para constituir uma ação, pois no mínimo eram necessárias duas personagens. Ésquilo, por sua vez, foi o primeiro a usar dois atores em suas peças, diminuindo a importância do coro e enfatizando a importância do diálogo. Coube a Sófocles introduzir três atores e a 
cenografia na tragédia. O desenvolvimento da ação está ligado à evolução das ações do ator:

Pois se nos comovemos com a sorte das personagens, é evidente que esta emoção só se pode enriquecer com as diversas vicissitudes a que elas estão submetidas; e se nos interessamos pelas suas virtudes ou pelas suas paixões, é igualmente evidente que este interesse só pode ser avivado ao ver como elas reagem às diversas peripécias que vêm pô-las à prova. (ROMILLY, 1997, p.39).

Entende-se, portanto, com o que afirma Romilly (1997, p.44), que o teatro grego não tende a ser predominantemente psicológico. A psicologia só adquiriu um terreno sólido na medida em que uma ação mais desenvolvida conferia-lhe um destaque maior. Euripedes, por exemplo, encheu seu teatro de artificios, de surpresas, de confusões e de reconhecimentos. Ele intensificou os episódios e as personagens. Pode-se dizer que diversificou a intriga e a tornou mais comovente.

\section{A tragédia segundo Albin Lesky}

Servimo-nos até então dos estudos sobre a tragédia feitos por Jacqueline de Romilly. Ao aproximar o estudo da tragédia antiga com o conceito de tragédia tal como hoje o entendemos, deparamo-nos com diversos sentimentos, virtudes e vícios, que são representados na tragédia antiga, o que nos dá modelos e exemplos para compreendermos a existência do homem, quer nos aspectos de vilania (Clitemnestra), quer de bondade e honradez (Antígona). A seguir, nossas reflexões serão centradas de acordo com o teórico Albin Lesky. Segundo o autor (1990, p.49), faz parte tanto da tragédia grega quanto da comédia o uso da máscara; seu uso nas culturas primitivas é múltiplo, a mais frequente é a máscara protetora; a menos frequente é a máscara mágica que transfere ao portador a força e as propriedades dos demônios por ela representados. Dessas duas a mais usada na tragédia é a máscara mágica, pois nela se encontra o poder da transformação em que se baseia a essência da representação dramática. Foi usada principalmente ao culto das grandes divindades da natureza e do crescimento; mas, especialmente desempenhou seu papel mais relevante no culto do deus Dioniso, ao qual fazia parte a tragédia (LESKY,1990, p.49). Ora, a máscara é produto artesanal até hoje fabricado em diferentes povos, incluindo os habitantes das ex-colônias africanas de língua portuguesa, como a Guiné-Bissau, Cabo Verde, São Tomé e Príncipe, entre os demais.

Lesky constatou, em suas pesquisas, que o uso da máscara é antiquíssimo até mesmo pelos gregos devido à máscara estar ligada ao culto das grandes divindades da natureza e do crescimento. O drama satírico e a tragédia grega se relacionam essencialmente. Um surgiu do outro. A máscara é elemento dionisíaco, orgiástico, foi com ela que o drama se originou, com ela até hoje tem-se a representação teatral. Em o Banquete, no momento em que Sófocles exige que Agaton e Aristófanes assegurem que o mesmo autor deveria ser tão hábil na comédia quanto na tragédia, essa simbiose pode ser exemplificada. Essa semelhança entre esses dois gêneros se evidenciava porque, como assinala Lesky, os sátiros também cantaram ditirambos, ou seja, cantos religiosos destinados à adoração de Dioniso. (1990, p.53). A história registra que os sábios alexandrinos refletiam também sobre a origem da tragédia; viram-se obrigados a adotar uma posição frente a Aristóteles, no sentido de que somente na época em que a tragédia já havia encontrado sua forma definitiva é que Pratinas de Fleio (princípios do século V) teria introduzido o drama satírico em Atenas. (LESKY, 1990, p.55). 
Albin Lesky também constatou que os sábios alexandrinos só enxergaram a contradição entre Pratinas, "o inventor" do drama satírico, e a doutrina aristotélica. Esses sábios optaram por procurar a origem da tragédia em explicações, ensinamentos, registros históricos e em lugares que lhes eram familiares como, por exemplo, na cidade de Alexandria. Naquela época, Lesky observa que estava em voga forte inclinação para tudo quanto fosse campestre, simples, sem rebuscamentos, e a tudo que dissesse respeito ao gosto popular. Manifestaram-se, então, os costumes rurais áticos das oferendas e das vindimas, diversões campestres, como o saltar sobre os odres. Essas práticas haviam se convertido em coisas dignas de apreço e de conhecimento. Nesse ambiente é que cultuavam Dioniso, apreciado em solo campestre, motivador da relação entre a origem da tragédia com as festas rurais da Ática. Horácio é o testemunho mais conhecido da teoria, segundo a qual, o cantor campesino entoava outrora seu canto "trágico" para obter um bode como prêmio, e somente mais tarde é que se teria acrescentado a isso o drama dos Sátiros. (LESKY, 1990 , p.56). Para o povo grego, todo o seu mundo está cheio de forças da natureza vistas de um modo pessoal, forças delicadas e amáveis; forças perigosas, rudes e alegres. As mais fortes são as dos sátiros ou silenos. (LESKY, 1990, p.57).

As máscaras representam as tragédias gregas, exemplificam os sentimentos de pesar, tristeza, tédio, medo, horror, pânico, perplexidade, pavor e piedade. É possível que nas representações mais antigas de sátiros observemos esses seres com o corpo coberto de pelos hirsutos, e a vestimenta de pele de Sileno de Papo, que ele conservou, é um resíduo disso, assim como a tanga de pele dos sátiros representada no vaso de Nápoles.

Os cavalos não têm couro peludo, mas os bodes têm, inclusive a barba deles possibilita inferir a possibilidade de que os sátiros, desde o princípio, tivessem diversos atributos animais, que fossem simplesmente animais selvagens, pois, é assim que aparecem tanto nas tragédias de Sófocles, quanto nas de Eurípedes. Diante dessas considerações, é provável, que, por causa da sua lascívia, bem nítida e profundamente arraigada na natureza desses demônios da vegetação, tenham sido chamados de bodes, sem que os atributos animais coincidissem em todas as minúcias com os dos bodes, pois, também para os antigos o bode era animal que caracteriza a lascivia. (LESKY, 1990, p.60).

Corrobora com Albin Lesky a professora Kathrin Rosenfield ao expressar que “tragos significa [...] 'bode', [...] como a 'parte baixa' (os genitais e os pés do bode) do deus Pã são o signo da errança inextrincável na materialidade do mundo e nas ambiguidades da linguagem". Segundo Kathrin, "na concepção platônica do termo tragos, ressoa [...] puberdade, primeiros desejos, lascivia e lubricidade, ou seja, a dimensão do desejo físico que põe em perigo a parte racional da alma e com ela a vontade, a intenção e a razão do sujeito" (ROSENFIELD, 2006, p.343). A origem do termo trágico, verificada por Rosenfield, coincide com o verbete "bode", encontrado em Chevalier (2006). Segundo o autor do Dicionário de simbolos, o bode é um animal trágico que deu seu nome "a uma forma de arte: literalmente, tragédia que significa canto do bode". Ao conceituarmos "trágico", verificamos que "o termo tem uma ampla polissemia" defini-lo é, portanto, tarefa árdua e complexa.

A tragédia grega tornou-se completa quando coincide o gênio de Ésquilo (525456 a.C.) e a grande época de Atenas. Sabe-se que as guerras pérsicas constituem o capítulo decisivo na biografia de Ésquilo. Um grande marco na vida desse autor foi ele ter estado em Maratona, onde tombou o irmão do poeta, Cinegiro. Em Salamina, Ésquilo presenciou graves abalos provocados pela dissolução e transformação do antigo estado aristocrático. Em 510 a.C., encerra-se a época da tirania. Apesar dos longos anos de tranquilidade e do desenvolvimento da cidade, não se mostrou a solução definitiva dos conflitos. (LESKY, 1990, p.79). O que ameaçava a Grécia, no 
caso de uma submissão voluntária, não era uma cruel tirania, nem era a devastação da vida econômica, já que estas não eram das piores no grande império. Tratava-se, pois, da liberdade que foi a única coisa que assegurou a vida espiritual dos gregos nas décadas seguintes. Entre calmarias e conflitos que a história nos conta, está a percepção e a sensação dos momentos que Ésquilo percebeu, dando-lhe mote e inspiração para elaborar as tragédias que, ainda hoje, podemos apreciá-las. Como já dito, o fato de Ésquilo ter estado em Maratona foi decisivo na vida desse autor, tanto que ele deseja preservar viva a tragédia na posteridade. Esse tragediógrafo escreveu muitas peças, mas temos acesso somente a seis delas, como, por exemplo, a trilogia Oréstia. Albin Lesky atesta (1990, p.85) que Oréstia é uma das maiores criações da arte humana, é uma obra de magnificência superior. Aprender e conhecer através da dor é uma ideia que predomina em toda a grandeza e luminosidade dessa trilogia. Nas duas primeiras peças da Oréstia - Agamêmnon e As Coéforas - observa-se uma descrição lírica de estados de alma e de oração e, por outro lado a ação.

Tanto Romilly (1997) quanto Lesky (1990) afirmam que a tragédia grega sempre permaneceu estreitamente vinculada ao teatro de Dioniso, situado na encosta Sul da Acrópole, nas imediações do templo de Eleutério. Dioniso e o mito são dois elementos básicos existentes na tragédia grega. A Dioniso não basta atos de adoração e sacrifícios. Ele quer a devoção máxima e exclusiva, arrasta-o para o horror do seu culto e, pelo êxtase, eleva-o acima de todas as misérias do mundo. Configura-se em Dionísio não só o rótulo de deus do vinho, mas também toda a incitante vida da natureza, toda a força criadora configurou-se na figura desse deus. Em seu culto orgiástico, a própria natureza arranca o homem à instabilidade da sua existência, arrasta-o para o interior do mais profundo reino de sua maravilha, a vida, levando-o a conquistá-la e a senti-la de forma nova. É elemento básico da religião dionisíaca a transformação. O homem arrebatado pelo deus transportado para o seu reino por meio do êxtase é diferente do que era no mundo quotidiano. (LESKY, 1990, p.61)

\section{A tragédia aristotélica}

No estudo da tragédia grega, os dois autores, que subdividiram este capítulo, certamente utilizaram-se da indispensável obra do filósofo grego Aristóteles. Elegemos o livro Poética, tradução de Eudoro de Souza (1993), para indispensáveis considerações acerca da tragédia. Para o estagirita, a tragédia teria nascido de improvisos, proveniente de formas líricas como o ditirambo (canto coral em honra a Dioniso). Em sua definição, a tragédia é uma imitação de homens superiores, de caráter elevado. Sua atuação era ilimitada no tempo; essa imitação da ação era completa e de certa extensão, em linguagem ornamentada e com as várias espécies de ornamentos distribuídos pelas diversas partes do drama; imitação que se efetua não por narrativa, mas mediante atores e que, suscitando o "terror e a piedade", tem por efeito a purificação dessas emoções. (ARISTÓTELES, 1993, p.37).

Linguagem ornamentada para Aristóteles é aquela que tem três características básicas: ritmo, harmonia e canto. Ao utilizar de modo separado cada uma das espécies de ornamentos, significa que algumas partes da tragédia adotam só o verso, outras também o canto. O meio pelo qual os atores efetuam a imitação é por elocução (composição métrica) e por melopeia (aquilo cujo efeito a todos é manifesto). Por ser uma ação, a tragédia é executada mediante personagens que agem e que diversamente se apresentam, conforme o caráter e o pensamento (porque é segundo estas diferenças de caráter e pensamento que nós qualificamos as ações). Duas são as causas naturais que determinam as ações: pensamento e caráter; e, nas ações [assim determinadas], tem a origem a boa ou a má fortuna dos homens. (ARISTÓTELES, 1993, p.39). 
Aristóteles (1993, p.39-40) identifica as partes da tragédia: o mito, o caráter, a elocução, o pensamento, o espetáculo e a melopeia. Mito é a imitação de ações, ou seja, a composição dos atos. Caráter é o que nos faz dizer das personagens, que elas têm essa ou aquela qualidade. É o que revela certa decisão ou, em caso de dúvida, o fim preterido ou evitado, por isso não tem caráter os discursos do indivíduo em que, de qualquer modo, se não revele o fim para que tende ou repele. Elocução é o enunciado das palavras por meio das personagens. Pensamento é tudo aquilo que as personagens demonstram para manifestar sua decisão. Consiste em poder dizer sobre tal assunto o que lhe é inerente e a esse convém.

Segundo o autor, o espetáculo cênico é o mais emocionante, mas também é o menos artístico e menos próprio da poesia. A realização de um bom espetáculo mais depende do cenógrafo do que do poeta. Melopéia é o principal ornamento da tragédia grega. (ARISTÓTELES, 1993, p.45).

Aristóteles (1993, p.39) afirma também que a tragédia não é só imitação de uma ação completa, mas também de casos que suscitam o terror e a piedade, e essas emoções se manifestam principalmente quando nos deparamos com ações paradoxais e perante casos semelhantes.

Segundo ele, o mito não deve representar um profano que se precipite da felicidade para a infelicidade. Se é certo que semelhante situação satisfaz os sentimentos da humanidade, também é certo que não provoca terror nem piedade; porque a piedade tem lugar a respeito do que é infeliz sem o merecer, e o terror, a respeito do nosso semelhante desditoso, pelo que, neste caso, o que acontece não parecerá terrível nem digno de compaixão. O mito é a imitação das ações, a composição dos atos. O elemento mais importante da tragédia é a trama dos fatos, pois a tragédia - como antes aqui se observou - não é imitação de homens, mas de ações, ações de vida, de felicidade e infelicidade. Importante salientar que tanto uma quanto a outra residem na ação, e a própria finalidade da vida é a ação, não uma qualidade. Sem ação não poderia haver a tragédia.

Embora não se tenha provas concretas sobre a origem da tragédia, é possivel afirmar que o drama satírico e a tragédia se relacionam essencialmente; uma dessas formas deve ter surgido obrigatoriamente da outra (ARISTÓTELES, 1993, p.52). Não se sabe qual delas surgiu primeiro, de todo modo, se torna primordial fazer um registro de pormenores sobre aqueles poetas.

\section{Os poetas trágicos ou tragediógrafos}

Os principais tragediógrafos foram estudados de modo exemplar tanto na obra de Albin Lesky (1990) como, depois, por Jacqueline de Romilly (1997). Os mais consagrados são: Ésquilo, Sófocles e Eurípedes, que lutaram pela continuidade e vitória no concurso dramático e pela imortalidade na história do pensamento. Por séculos, o teatro de Dioniso continuou sendo o lugar das representações dramáticas, até o momento em que os romanos, em um ato de barbárie, transformaram a arena em um lugar para a luta de gladiadores e a caça de animais selvagens. A análise sobre as tragédias e a história desses autores faz-se, muitas vezes, necessária para a compreensão das ações dramáticas da atualidade, representadas, hoje, em novelas, peças de teatro, cinema, letras de músicas, enfim, na cultura ocidental dos últimos séculos. Ao que pese o objetivo desta reflexão, serão citados fragmentos de três tragédias: 
Exemplo 1 - Agamêmnon:

\section{A Sentinela}

Aqui no alto do palácio dos Atridas

Aos deuses todos peço há muitos, longos anos que me liberem da vigília cansativa.

Firmado em meu braço dobrado, sempre atento, igual ao cão fiel, de tanto olhar o céu noite após noite agora sei reconhecer a multidão inumerável das estrelas, senhora lúcidas do firmamento etéreo, indicadoras dos invernos e verões em seu giro constante pela imensidão.Espreito a todo instante o fogo sinaleiro que nos dará notícia da queda de Tróia; são ordens da mulher de ânimo viril, rainha nossa, persistente na esperança. Sempre que faço por aqui meu leito duro e deito molhado de orvalho, sem dormir e abandonado pelos sonhos de outros tempos (em vez de sono tenho medo, grande medo que afasta sempre minhas pálpebras pesadas), tento cantarolar, dizer alguma coisa que me desperte do torpor e me estimule, mas são soluços que me saem da garganta, pois choro as muitas desventuras desta casa outrora tão feliz, tão infeliz agora! Que venha, venha logo o protelado termo de minhas incontáveis atuais fadigas com a mensagem clara inda não recebida! (Agamêmnon - versos 5 a 45)

No trecho acima, o Sentinela pede aos deuses que o liberem da vigília que perdura por longos anos. Lamenta o desconforto e o abandono que sente ao esperar o fim da guerra em Tróia, pois é missão do Sentinela informar à rainha, Clitemnestra, quando houver o fogo sinaleiro, sinal da notícia da queda de Tróia. Embora bastante deprimido e com medo, logo, logo o Sentinela muda de expressão e de ação ao ver o sinal tão esperado:

É o sinal! É o sinal! Meus próprios olhos vêem!

Eis a noturna luz que mudará decerto a treva em pleno dia! logo vamos ter em Argos muitas danças e sonoros cantos!

Falo alto e forte que me escute bem a esposa de Agamêmnon em seu leito régio e faça reboar pelo palácio todo

um grito estrepitoso de contentamento

se é verdadeira esta revelação das chamas

e finalmente Tróia forte foi vencida.

Começarei eu mesmo a festa; estou dançando!

A sorte dos meus amos é também a minha

e a mensagem da chama vista de tão longe

é o lance mais feliz de toda a minha vida!

Volte o senhor deste palácio são e salvo

e possa eu logo estreitar-lhe a mão bem-vinda!

Quanto ao demais, silêncio! Um peso muito grande

prende-me a língua mas a sua própria casa,

se possuísse voz, revelaria fatos

conhecidíssimos por muitos dos argivos;

hão de entender-me claramente os que já sabem;

não saberão os outros; quando quero, esqueço.

(Agamêmnon - versos 30 a 45). 
Ao saber da vitória dos Argivos sobre Tróia, o Sentinela mostra alegria, tanto pela vitória dos helenos na guerra, quanto pela libertação do seu padecimento.

\section{Exemplo 2 - As Coéforas:}

\section{Orestes}

Ela feriu meu pai ou não? A prova certa

Está aqui: o pano avermelhado

pelo pino punhal que Egisto manejou

Os vestígios de sangue e o tempo decorrido

esmaeceram os bordados multicores.

Agora posso me aplaudir abertamente, Agora posso lamentar-me no momento De ver este lençol que recobriu meu pai, Mas choro pelo feito, pela punição

$\mathrm{E}$ até por nossa raça, pois desta vitória

Guardo somente uma desmesurada mácula.

\section{Coro}

Nenhum mortal consegue atravessar

A vida inteira livre de amarguras.

Uma tristeza hoje, outra amanhã...

Orestes sofre pela morte de seu pai. Assassinato provocado por Clitemnestra (mãe de Orestes e esposa de Agamêmnon) e Egisto. Para vingar seu pai, Orestes mata sua mãe e o amante dela. Mesmo tendo se aplaudido por ter vingado seu pai, ele lamenta e chora por ser o assassino de sua mãe. Sofre pelo fato de sua mãe ser assassina e adúltera; por ter sido vendido e vivido longe de seus entes queridos e, depois, por ter de vingar a morte de seu pai. Os dois exemplos mencionados demonstram a súplica dos personagens, que, logo mudam de ação. A criação literária desse autor encontrou na trilogia a forma apropriada que lhe permite ultrapassar o segmento singular do acontecimento, pois somente nas trilogias é que o autor se propõe a revelar todo o seu sentido, Lesky atesta que só se pode compreender o poeta por inteiro em sua Oréstia. (LESKY, 1990, p.97)

Segundo Aristóteles (1993, p.31), Ésquilo foi o primeiro poeta a acrescentar o segundo ator à tragédia, também reduziu as partes do coro e assegurou a primazia à parte falada. É, portanto, um grande avanço na expressão dramática o diálogo em cena de dois atores. Mostra-se, portanto, o progresso dramático com a atuação de três atores na Oréstia de 458 a.C. Reconhecer a participação divina e humana no infortúnio da culpa sentida pelos homens é um dos motes desse autor. O poeta não se satisfaz com a imagem de deuses que, por meio da culpa e da ofuscação precipitam o homem na ruína. O sofrimento que surge da ruína em que o homem se encontra é o caminho que leva o homem à compreensão e lhe permite reconhecer a eterna validade das leis divinas. Sófocles, entretanto, constrói seu herói aceitando seu destino, não tão submetido às ações e decisões dos deuses.

"A Tragédia do Homem Solitário" é uma expressão de que Lesky (1990) se utiliza para tratar da obra de Sófocles. Adiante, o autor ocupar-se-á de Eurípedes, utilizando-se da expressão "A Tragédia das Paixões" para elucidar o conceito de tragédia na produção dos dois tragediógrafos. 
Sófocles 5 é o tragediógrafo que pertence ao apogeu de Atenas. Na batalha de Salamina, embora fosse muito jovem, foi designado a conduzir o coro que celebrou a vitória dos atenienses. Presenciou a construção da Acrópole e conheceu o império Grego. Diferente de Ésquilo e Eurípedes, Sófocles nunca deixou Atenas. Embora tivesse assistido aos dissabores da guerra do Peloponeso, sempre demonstrou seu amor pela pátria amada. Esse amor patriótico se manifesta, em sua obra literária, no seu desempenho em cargos públicos e no serviço do culto de Atená.

Sófocles conscientemente aceitou o papel de sucessor de Ésquilo. Isso por que entendia que a concepção grega da essência da poesia, não busca a individualidade, mas sim a unidade expressiva que se permite de um poeta para o outro. Importante verificar que o que é trágico nos textos de Sófocles é a impossibilidade de evitar a dor. É esse o inevitável do destino (ou da moira grega) do ponto de vista humano. É significativo expressar que, pela primeira vez, a mulher aparece como representante do humano ao lado do homem com idêntica dignidade. As numerosas figuras femininas de Sófocles como Antígona, Electra, Dejanira, Tecmessa, Jocasta e outras consideradas de menor relevância como Clitemnestra, Ismena e Crisóstemis, iluminam com fulgor a elevação e a amplitude da humanidade de Sófocles. A descoberta da mulher é a consequência necessária da descoberta do homem como objeto próprio da tragédia. (JAEGER, 2001, p.328).

Sófocles substitui a trilogia - estabelecida por Ésquilo - e adere ao drama isolado, cujo ponto central é a ação humana. Foi na pureza da arte que ele encontrou seu caminho, considerado pelos classicistas e pela Antiguidade toda como sendo o apogeu do drama grego, pelo rigor de sua forma artística e pela sua luminosa objetividade. Sófocles pode ser chamado de clássico no sentido de que atinge o ponto culminante no desenvolvimento da tragédia, visto que ele consegue exprimir a mais elevada dignidade, obtida por quem leva um gênero literário à sua perfeição. É notória a sua posição no desenvolvimento espiritual da Grécia, o que se nota, sobretudo, na literatura. O mérito desse poeta é proveniente não do formal, mas na dimensão humana do ponto de vista ético, estético e religioso condicionados reciprocamente. (JAEGER, 2001, p.321).

É por meio desse tragediógrafo que a Grécia desenvolve a ideia de medida, considerada o mais alto valor. Também é nele que se encontra a clássica expressão poética como força divina que governa o mundo e a vida. (JAEGER, 2001, p.325).

Muitas considerações podem ser feitas quanto ao talento e à sabedoria de Sófocles, mas abordaremos, nessa reflexão, especialmente a tragédia Antígona. A maldição dos Labdácidas cuja ação aniquiladora é expressa na trilogia esquiliana, permanece ainda em Sófocles, especialmente na tragédia denominada Antígona. Sófocles viabiliza que Antígona e seu opositor Creonte a participarem na realização do seu destino pelo vigor das suas ações e o coro não se cansa de falar da transgressão da medida e da participação de ambos no infortúnio. Antígona está determina a sofrer, determinada para a dor pela sua própria natureza, ou ainda, foi eleita para aguentar a dor. Agonia que se converte em nova forma de nobreza. Esta eleição para a dor, revela-se de modo eminente no diálogo inicial entre Antígona e sua irmã Ismena:

\footnotetext{
${ }^{5}$ Esse poeta é filho de uma família abastada. Recebeu uma educação primorosa. Participou com sucesso na vida política e foram-lhe confiados papéis de músico. Também desempenhou funções religiosas. Sua carreira literária foi brilhante. Aos trinta anos de idade foi coroado pela primeira vez em 468. Teve muitos amigos, era amável e sociável. (ROMILLY, 1997, p.81).
} 
Comum no sangue, querida irmã, caríssima Ismena, sabe de algum mal, dos que nos vem de Édipo, que Zeus não queira consumar em nossas vidas? Nada - angústia, infortúnio, humilhação, desonra -, não há mal que eu não veja cair sobre ti, sobre mim. E Agora... Que novo decreto - propalam - é este que o general acaba de proclamar em toda a cidade? O que sabes? Ouviste algo? Ou ignoras que atacam a entes queridos nossos - malefícios vindos de inimigos? (SÓFOCLES, 1999, p.7).

Compreende-se o afundamento do herói na dor trágica, em vez de colocá-lo na injustiça, o que faz é revelar de modo patente em naturezas nobres o caráter iniludivel do destino que os deuses impõem aos homens. A irracionalidade desta Ate (ruína, insensatez, engano ou fatalidade) foi o que inquietou o sentido da justiça de Sólon e preocupou a época inteira, é um pressuposto do trágico, mas não constitui o problema da tragédia. Sófocles pressupõe a Ate. (JAEGER, 2001, p.331).

Com o sofrimento, o homem trágico torna-se o instrumento mais maravilhoso e mais delicado para o poeta. Com esse "instrumento", o poeta põe em ação todos os recursos da fantasia dramática. Observa-se que Sófocles tende a elevar e fazer brilhar a ação dramática. Ele leva o leitor ao âmago da cena. A solidão de Antígona tem por efeito isolar de modo progressivo a heroina de qualquer ajuda e de qualquer suporte humano "Ismene, minha irmã, minha querida irmã...". Estas palavras que abrem a narrativa são um apelo à ação comum. Antígona queria que Ismene a ajudasse a sepultar Polinice: “... e em breve mostrarás se tens caráter ou se a tua nobreza fizeste vileza." Ismene se recusa a agir. Diante da recusa da irmã, Antígona se fecha, se refugia em si mesma: escolhe a solidão, agirá sozinha (ROMILLY, 1997, p.92).

Diferente de Ésquilo e Sófocles, Euripedes se detém a produzir tragédias baseadas nas paixões, ou seja, não há mais a interferência divina. O homem mediante suas pulsões age e reage frente às situações que surgem. Como se observou antes, Lesky (1990) também tratou da obra de Eurípedes e, ao fazê-lo, utilizou-se da expressão "A Tragédia das Paixões".

Não há registro de que Euripedes (484 a.C.) 6 tenha realizado alguma atividade a serviço do Estado, mas em suas peças pode-se notar o quanto ele se esforçou por servir como poeta à sua pátria em tempo de crise. Os dramas euripidianos possuem uma visão de mundo nitidamente delineada, em todos os traços individuais. (LESKY, 1990, p.160).

Para Eurípedes, o destino do homem nasce do próprio homem, do poder de suas paixões, ou seja, o homem não recebe a ajuda ou a interferência divina. A obra desse autor é plena da problemática das antinomias, marcada por profundas contradições. Uma nova concepção surge a partir das tragédias de Eurípedes: a firme crença nas figuras dos deuses desaparecem e a autonomia do pensar e do sentir humano molda os personagens para as quais uma concepção do homem é mais decisiva que sua performa pelo mito. As tragédias desse poeta com seu peculiar modo de atuar e de sofrer colocam-se dentro de uma ordem estável no mundo. Nos textos dele Eros não é encarado como força objetiva, é encarado como paixão subjetiva. Eurípedes é atraído pelo poder do erótico, levado às raias do patológico. Medéia, por exemplo, ao ser traída pelo marido, mata seus próprios filhos com o intuito de se vingar do esposo, 
culpa-o pela morte dos filhos. Se isso não bastasse, ela impede que Jasón sepulte as crianças.

Exemplo 3 - Medeia:

Se Zeus pai não soubesse como te tratei

E como e quanto me ofendeste, esta resposta

À tua falação teria de ser longa.

Não deverias esperar, após o ultraje

Contra meu leito, que fosses passar a vida

Rindo de mim, tranquilo com a filha do rei;

Creonte, que te deu a filha para esposa,

Não haveria de querer impunemente

Expulsar-me daqui, onde cheguei contigo.

Chama-me agora, se quiseres, de leoa e monstro; quis apenas

Devolver os golpes de teu instável coração como podia.

Jasón

Mas também sofres. Nossas dores são as mesmas

Medeia

É claro, porém sofro menos se não ris.

Jáson

Minhas crianças! Que mãe perversa tivestes!

Medeia

Matou-vos a perfídia deste pai, meus filhos!

Jáson

Mas não foi minha a mão que lhes tirou a vida.

Medeia

Foi teu ultraje, teu segundo casamento!

Jáson

O leito abandonado justifica o crime?

Medeia

Essa injúria é pequena para uma mulher?

Jáson

Se ela é sensata. Para ti, tudo é ofensa.

Medeia (Apontando para as crianças mortas) 
Elas já não existem. Sofrerás por isso.

Jáson

Existem para atormentar-te em teu remorso.

Medéia

Os deuses sabem a quem cabe toda a culpa.

Jáson

Sabem também o quão tenebrosa é a tua mente

Deixe-me sepultar meus filhos e chorá-los!

Medéia

De modo algum! Com minhas próprias mãos eu mesma, hei de enterrá-los. Transportá-los-ei agora ao santuário de Hera, deusa das colinas, onde nem tu nem mais ninguém possa ultrajá-los violando-lhes o túmulo. Instituiremos solenes cerimônias na terra de Sísifo, visando à expiação desse terrivel crime. Irei de lá para a cidade de Erecteu, onde me acolherá o filho de Pandíon, Egeu. Morrerás miseravelmente aqui, colhendo - miserável! - os amargos frutos do novo casamento que tanto querias!

A antinomia presente nessa tragédia é o fato de a mãe privar-se da companhia dos filhos. Mata-os pelo simples fato de se vingar do marido. Prefere ficar ausente da presença dos filhos com a culpa de ter-lhes privado à vida para simplesmente fazer o marido sofrer. O domínio com que Medéia expressa seus argumentos e faz as palavras passarem logo de seu destino particular à ideia geral, mostra a desgraça social da mulher, que contrasta eficazmente com os brados do desespero que se percebe no interior do palácio. A dor da traição foi tão grande que a vingança pode ter-lhe causado satisfação. Nenhuma punição seria dada a Jáson pelo fato de ele ter traído Medéia e preferido a filha de Creonte. Sabendo da impunidade, ela mesma trata de puni-lo. (LESKY, 1990, p.172).

Nessa peça, Euripides se aprofunda na caracterização dos personagens, sobretudo no que se refere à alma feminina. O poeta considera deplorável o destino da mulher, pretende, portanto, fazê-la heroína da tragédia matrimonial burguesa. Medeia é um autêntico drama do tempo desse poeta, especialmente pelo conflito entre o egoísmo ilimitado do homem e a paixão ilimitada da mulher. Enquanto Jasão ostenta a prudência e a generosidade, Medeia faz reflexões filosóficas sobre a posição social da mulher, sobre a desonra violenta da entrega sexual (mesmo diante de um casamento) a um homem estranho, a quem é preciso seguir no casamento e comprar por um rico dote. Ela explica que o parto dos filhos é muito mais perigoso e heróico do que as façanhas dos heróis na guerra. (JAEGER, 2001, p.400).

Eurípedes foi o primeiro dos trágicos gregos a ter imaginado Electra e Orestes. Nesse intento, depois de terem cometido matricídio, instaura-se o sentimento de remorso nesses filhos, provocando assim reviravoltas duráveis. Subitamente horrorizados com o que fizeram; acalmado com o seu ardor, eles reencontram 
sentimentos completamente diferentes e lançam-se num arrependimento ilógico, conforme expressa Electra no verso 1182: "Quantas lágrimas, meu irmão, e eu sou a sua causa. Eu ardia, desgraçada, contra esta mãe que me criou, a mim, sua filha" (ROMILLY, 1997, p.132).

Depois do crime, segundo Euripedes, Orestes foi atormentado, correspondendo a um castigo divino, por terrores vãos da sua imaginação doente. Orestes é visto no seu leito, sofrendo, esgotado, transpirando; tem visões: toma a irmã por erínia, e quando Menelau lhe pergunta: "Que doença te destrói?" ele responde, como um homem a quem tais tormentos não surpreendem: "A consciência, por que sei que pratiquei uma ação terrivel”. (ROMILLY, 1997, p.132).

Em sintese, a tragédia clássica, como vimos até aqui, era destinada à adoração a Dioniso, portanto, um evento festivo. Porém, aos poucos, essas festividades deram lugar à forma teatral, mudança que ocorreu em 534 a.C., quando Téspis ${ }^{7}$ incitou a inclusão de espetáculos dramáticos nos festejos em honra a Dioniso. A tragédia passa a ter outro rumo: $1^{\circ}$ ) em Roma, ainda se representava tragédia no modelo grego, mas sem o reproduzir; $2^{\circ}$ ) tornam-se conhecidas as peças de Sêneca8 (século I a.C.) especialmente direcionadas antes à leitura que à representação, exercendo influência no teatro da Renascença; $3^{\circ}$ ) surge a primeira tragédia moderna - Sofonisba ${ }^{9}$ (1515), do italiano Trissino; $4^{\circ}$ ) no século XVII, a tragédia moderna tem seu apogeu, mas, nos séculos anteriores (XV ou XVI) se observa o surgimento da "tragédia burguesa", ou "tragédia doméstica", ou seja, trata-se mais de "drama social"; $5^{\circ}$ ) No século XIX, a tragédia desaparece por completo, em razão do surgimento do drama.

Ainda nessa direção, considera-se importante salientar que os teóricos da Renascença aderiram, a princípio, a doutrina de Aristóteles, mas fizeram acréscimos que foram aceitos em razão das alterações que as peças sofreram, gerando assim um tipo novo de tragédia, conforme explica Massaud Moisés:

Se esta não renovou os temas, continuando a buscá-los na Antiguidade [Idade Média], tendeu a uma simplicidade e a uma concentração que a tragédia grega desconhecia. Se aceitou em geral a teoria tradicional do herói mediocremente virtuoso, subverteu a escola dos casos trágicos estabelecidos por Aristóteles. E abandonou os assuntos de terror. [...] (MOISES, 1974, p.158).

Diante da análise do percurso da tragédia, podemos citar que uma das diferenças existentes entre a tragédia clássica e a moderna tem a ver com a concepção de herói. O herói na tragédia antiga luta contra a inexorabilidade do Destino (fatum ou anhanké], determinado pelos deuses. Antígona, por exemplo, sepultou seu irmão mesmo sabendo do seu derradeiro fim, a morte. A tragédia moderna, do século XVII,

\footnotetext{
7 Téspis, considerado o primeiro ator da história do teatro ocidental, colocou-se à parte do coro como solista, assim criou a forma de representa-lo por diálogo. Téspis apresentava o espetáculo e se envolvia num diálogo com o condutor do coro. Essa inovação se desenvolveu posteriormente na tragédia, etimologicamente tragos (bode) e ode (canto). (BERTHOLD, 2006, p.105)

8 Lúcio Aneu Séneca nasceu em Córdoba (Espanha - 4 a.C). Sua obra literária e filosófica é considerada como modelo do pensador estóico durante o Renascimento. Inspirou o desenvolvimento da tragédia na dramaturgia européia. Destacou-se como estilista literário. (SÊNECA, 2000, p.8)

19 Sofonisba é a primeira tragédia regular da Literatura italiana, escrita por Guivan Giorgio Trislaig.
} 
focaliza a luta do indivíduo contra as forças do meio social, convertidos em dualidade, conduzindo-o a um impasse sem solução, sem apelo à desgraça e, mesmo, à morte. O herói moderno recebe seu destino de modo inesperado, sem aviso. (MOISÉS, 1974, p.157-158).

A tragédia antiga apresenta a dor, o sofrimento, o medo e outros sentimentos que propiciam a reflexão sobre a existência humana. Abarca temas que expressam as mais puras sensações e inconstâncias do homem. Conflitos que pesam não só na mente, mas também no coração (sentido figurado). As tramas tão bem entretecidas comovem o leitor. Cumpre, portanto, seu objetivo de provocar terror e piedade às manifestações das personagens que atuam de modo a inquietar o leitor. As mesclas de sentimentos demonstrados pelos personagens da Tragédia grega é o que a torna mais rica.

\section{Tragédia Moderna}

O trágico não vem a conta-gotas.

(Guimarães Rosa, em Tutaméia terceiras estórias)

O conceito de trágico foi discutido pelos filósofos não só em relação à forma de arte que é a tragédia, mas também em relação à vida humana. Eles reconhecem que o ponto de partida desse estudo - o que é tragédia -, quer de maneira implícita, quer explicita, quase sempre parte da definição aristotélica de tragédia (imitação de acontecimentos que provocam piedade e terror aos personagens e que ocasionam a purificação dessas emoções). Embora, haja muitos pareceres filosóficos sobre este tema, tomaremos o conceito de Shopenhauer, segundo verbete do dicionário de Nicola Abbagnano:

A tragédia é a representação da vida em seu aspecto terrificante. É ela que nos apresenta a dor inominável, a aflição da humanidade, o triunfo da perfidia, o escarnecedor domínio do acaso e a fatal ruina dos justos e dos inocentes; por isso, ela constitui um sinal significativo da natureza do mundo e do ser. (ABBAGNANO, 1998, p.969)

A reação de terror e de piedade, como bem se observou entre os tragediógrafos gregos, persiste hoje diante de acontecimentos inesperados. Trata-se de sentimentos que evidenciam a perda, que os homens mantêm em sua história, desde o princípio de sua existência, sentimentos que afloram de modo similar

Raymond Williams (2002), na obra Tragédia Moderna, questiona-se sobre a tragédia, indagando-se se, em nosso tempo, a tragédia seria uma resposta à desordem social. Para isso, ele reflete sobre a separação entre pensamento social e pensamento trágico, o que o autor nem sempre considera algo facilitado, uma vez que:

Contrariamente ao que conheciam como a ideia de tragédia, enfatizaram os poderes do homem para modificar a sua 
condição e pôr fim a uma grande parte do sofrimento que a ideologia da tragédia parece ratificar. A ideia de tragédia dito de outro modo foi explicitamente contraposta à ideia de revolução [..]. E, assim, descrever a tragédia como uma resposta às desordens sociais, e valorizá-la enquanto tal, implica romper, aparentemente, com essas duas grandes tradições. (WILLIAMS, 2002, p.91).

Para Williams, a ideia de tragédia na sua forma usual excluiria a experiência trágica que é social. Mas trata-se de uma contradição significativa, segundo ele, uma vez que em nossa época são conexões entre revolução e tragédia, vividas e conhecidas por nós ainda que não sejam reconhecidas como ideias propriamente ditas, o que, nas palavras do autor, envolve sempre o sofrimento:

Uma época de revolução é tão somente evidentemente uma época de violência, deslocamento e de longo sofrimento que é natural senti-la como uma tragédia no sentido cotidiano da palavra. No entanto, quando o evento se torna história, é normalmente visto de forma inteiramente diversa. Um grande número de nações olha para o passado de revoluções da sua própria história como para a era de criação da vida que é agora mais preciosa. A revolução bem-sucedida, poderíamos dizer torna-se não uma tragédia, mas uma épica: é a origem de um povo, e do modo de vida pelo qual tem preço. Quando lembrado, o sofrimento é simultaneamente honrado ou justificado. Aquela revolução específica, dizemos, foi uma condição necessária da vida. (WILLIAMS, 2002, p.92).

Seria a história da humanidade composta de tragédias? Na linha de reflexão do autor, "A revolução enquanto tal é, num sentido comum, tragédia, um tempo de caos e sofrimento" (WILLIAMS, 2002, p.93), uma tragédia que se tornará épica, mas como revolução trata-se de uma ação total dos homens que vivem no presente: "A ação trágica tem suas raízes em uma desordem que, de fato, numa etapa específica pode parecer ter sua própria estabilidade" (WILLIAMS, 2002, p.94).

O texto que trata da tragédia moderna intitulado "De herói à vitima" do livro Tragédia moderna lembra que a época de Shakespeare a estrutura da tragédia já se encaminhava para o que agora conhecemos, com ênfase no destino pessoal "um homem individualizado, com as suas próprias aspirações, com sua natureza própria inserido na ação que acaba por levá-lo à tragédia." (WILLIAMS, 2002, p.120). Para o autor, o gênero de teatro muito cultivado nos séculos XV e XVI, dava continuidade à tradição das moralidades, tinha por finalidade a "sátira moralizante". São formas que, no entanto, se encontram em processo de mudança muito ativa, e o processo comum da vida é visto numa experiência individual, um homem que acaba por encontrar seus limites trágicos, como o absoluto da morte. Interessante observar que, antes do limite absoluto da morte o indivíduo em seu drama descobre, explora e põe à prova a profusão de seus limites, descobrindo-se como humano, ser fragmentado em sua ordem e totalidade. A tragédia pessoal está no centro da ordem pública: o herói na tragédia elisabetana é ainda usualmente o príncipe marcado por uma alta condição social, ainda que possa ser visto de uma forma diferente:

Se na tragédia grega a condição social do herói, contudo que implicava de hereditariedade, parentesco e obediência encerra e envolvia a personalidade, desenvolvida apenas na exata medida requerida pela ação geral, encontramos agora na tragédia 
elisabetana uma personalidade inserida nos limites de uma condição similarmente caracterizadora e, ao mesmo tempo, estendendo-se para além desses limites; o conflito que pode então resultar dessa coexistência é, uma das fontes da tragédia. (WILLIAMS, 2002, p.123)

Para tratar do ritmo da tragédia como ritmo sacrificial, Williams no capítulo "Resignação trágica e sacrifício" examina a condição do homem despedaçado pelo sofrimento e levado à morte. Nesse caso, a ação seria mais do que pessoal por que, enquanto isso outros tornam-se inteiros, são curados, enquanto ele é fragmentado. $\mathrm{O}$ autor acredita que para discutir o sacrifico seja necessário um contexto especifico e que já na tragédia da cultura grega sua origem ocorre em um ritual ativo de sacrificio, uma hipótese debatida, diz o autor por que se baseia numa antropologia romântica, que se apropriava de padrões ritualísticos, abstratos, desvinculados de uma sociedade real e da história. "Em nossa própria cultura, a ideia de sacrifício, na qual um homem é morto para que um conjunto de homens possam viver - ou viver mais plenamente - foi por nós abandonada quase que por completo" (WILLIAMS, 2002, p.205) ${ }^{10}$

A expressão "bode expiatório", ligada ao sacrifício, é concebida como trágica em sua ação e trágica também é a morte do bode expiatório, entendida como "renovação da nossa culpa geral". Em "O desespero trágico e revolta", o desejo de uma nova forma dramática é visto a partir de 1945, quando Albert Camus escreveu "Hoje em dia a tragédia é coletiva" (CAMUS apud WILLIAMS, 2002, p.228). Trata-se de posturas em relação à vida que são trágicas reconhecidas por Camus como "o absurdo" e essa "absurdidade", conforme observa Williams é antes uma experiência, e não uma doutrina.

É um reconhecimento de incompatibilidades entre a intensidade da vida material e a certeza da morte; entre o insistente esforço de racionalização do homem e um mundo não-racional em que ele habita. Essas contradições permanentes podem intensifica-se em circunstâncias especificas: o de cair da vida espontânea em uma rotina mecânica; a consciência do nosso isolamento em relação aos outros e até a nós mesmos. (WILLIAMS, 2002, p.228).

Nas palavras de Williams, o absurdo e o desespero relacionam-se a uma condição absoluta na obra de Camus, uma parte especialmente significativa da sua própria revolta humanista. Assim, o humanismo trágico de Camus é uma recusa ao desespero, mas a tragédia reside na condição geral: "enquanto o sofrimento é genuinamente coletivo, a revolta é inevitavelmente individual." (WILLIAMS, 2002, p. 238).

A tragédia em quase todos os sentidos antigos é rejeitada por Brecht, o que significa dizer que Brecht vivenciou o peso do sofrimento na moderna tragédia da Europa que, segundo Williams (2002, p.248) "não é hiperbólica", mas precisa e literal, "uma chave para a nossa literatura", uma vez que Brecht vivenciou ao menos dois

${ }^{10}$ Conhecemos a idéia, de que outras culturas e periodos, mas ela detém um significado emocional em apenas um caso: como o elemento central da fé cristã. Ali, o modo como essa idéia é fixada prova o quanto nos afastamos da idéia enquanto tal, uma vez que Jesus, o homem, é também para os crentes o Filho de Deus, e a ação, para que seja significativa, deve ser vista como parte de uma história divina, mais do que como algo que pertence a uma história meramente humana. (WILLIAMS, 2002, p.206) 
modos decorrentes da moderna tragédia na Europa: a identificação de um sistema político como uma causa principal de sofrimento e a descoberta da esperança na luta contra ele.

Se a realidade do sofrimento entre em cena com o seu peso natural, o espectador se desestrutura, pois tornar-se-á um participante, e, no entanto, como participante, ele pode apenas condenar ou compreender o sofrimento por intermédio de algum principio ativo, que ele, no entanto, não consegue achar. $\mathrm{O}$ principio o que parece faz parte do mundo que ele rejeita. Um sistema maléfico é protegido por uma falsa moralidade. (WILLIAMS, 2002, p.249).

A exemplo da maior parte do drama moderno, o dramaturgo, "em seus melhores momentos", se lança - e atinge - a próxima e necessária etapa: sim, as coisas são desse modo por essas razões, mas a ação é continuamente reencenada e poderia também ser de outra forma (WILLIAMS, 2002, p.262).

Diante desse transcurso na reflexão sobre a tragédia, quer como gênero literário, que como palavra designada para expressar momentos funestos, parece ser importante considerar nesta reflexão o que se pode entender por conflito trágico? Para José Pedro Serra, na obra Pensar o Trágico - Categorias da Tragédia, a ideia de conflito implica a de um antagonismo, de uma posição, embate de forças contrárias:

[...] num conflito, poderes, princípios, tendências, indivíduos, nações organizam-se em torno de polos opostos reclamando para o mesmo objeto determinações contraditórias. A ideia de oposição antagonista não implica por si própria qualquer tragédia". (SERRA, 2006, p. 197-198).

Ao tratar do estabelecimento de oposições, o autor considera esse procedimento um passo importante para uma compreensão racional da realidade e, "por consequência, no abandono da primitiva visão mítica do mundo, onde as fraturas e os hiatos - a começar pela distinção entre o sujeito e o objeto - não têm lugar." (SERRA, 2006, p.198). Em que momento uma oposição ou um embate torna-se conflito? Segundo o autor, é quando os princípios opostos exigem, simultaneamente para o mesmo objeto ou situação, determinação ou solução contraditória inconciliáveis. Assim, Serra compreende que, em lugar de uma harmoniosa unidade de contrários, o conflito trágico traga consigo uma perturbação da origem do real ao pelo menos ameaça de desordem: "o conflito apresenta-se na Tragédia Grega como algo dissonante, como elemento de fractura na ordenação de estabilidade cósmica, entrevendo neste facto a sua natureza especificamente trágica." (SERRA, 2006, p.198).

A vivência dos homens é marcada pelo desejo ardente de liberdade e pela busca intensa do sentido da vida. Estamos suscetiveis à fatalidade, vulneráveis ao que nos provoca dor e sofrimento. O trágico desperta o sentimento de impotência sofrida; somos individuos impotentes para alterar um destino trágico, nada sabemos por antecipação. Entre os gregos, o herói diz sim ao destino (moira), restando-lhe assumir a fatalidade como marca indelével na trajetória expressa pelos tragediógrafos.

No segundo item neste artigo, observamos que tanto Sófocles quanto Ésquilo expressaram, em suas tragédias, uma forte influência dos deuses na vida do homem. Diferente deles, Euripedes mostrou um homem desassociado das deidades, autônomo sobre os seus atos. Há, portanto, duas hipóteses a serem consideradas nessa reflexão: o homem está subjugado, forçado a sofrer de modo pacífico diante da 
vontade e da imposição alheia ou ele é livre para decidir acerca de seus atos, assumindo as responsabilidades das consequências advindas das suas decisões?

Segundo Serra (2006, p.292), o homem trágico sabe que a sua vida é dirigida pela vontade dos deuses, tanto alegrias quanto tristezas. "Na tragédia, o homem é o breve sorriso pelos deuses consentido, também está sujeito a forças obscuras e 'demoníacas', a poderes sombrios e enganadores".

Pode-se entender, então, que o homem trágico em nenhuma circunstância age por si próprio, é escravo dos poderes superiores? Serra responde que o homem trágico não é um títere sem vontade ou sem voz. Ele possui consciência que transfigura a realidade, mas isso não lhe dá condição de ser livre, especialmente no que se refere a escolhas, mas lhe dá condições de principiar uma ruptura "no impensado devir das coisas, que impede o homem de ser pedra entre as pedras, objecto entre objectos." (SERRA, 2006, p.293).

O autor afirma que "ao homem pode ser imposto um destino, mas só o homem pode merecer ou falhar o destino" (2006, p.294). Depreende-se, portanto, que a tragédia não reduz o homem a um fantoche, nem o homem está fadado a comandos alheios.

A outra hipótese é expressa pelo homem como dono das suas decisões, livre para escolher, sem interferência dos deuses? O homem está constantemente envolvido em situações reais, está sempre no meio de forças e de influências concretas, impossibilitando a existência de liberdade absoluta, conforme podemos entender pela explanação de Pedro Serra:

Se o homem não é totalmente livre, tal não significa que ele seja totalmente vítima da situação onde se insere e que não possa escolher; desde ponto de vista, isso é, do ponto de vista da liberdade de escolha, o problema ressurge, não há ingênuo e inocente, quando se reafirma o efectivo exercício da vontade, realizando uma escolha. (SERRA, 2006, p. 295).

Diante das duas proposições de Serra, notamos que o homem não é e nunca foi um fantoche alheio ao que acontece na vida e no mundo; nem foi e nunca será um ser livre que tudo pode fazer como bem lhe aprouver.

O filósofo Roberto Machado, em seu livro O nascimento do Trágico de Schiller a Nietzsche (2006), especialmente no capítulo "Schiller e a representação da liberdade" expressa que o dramaturgo Schiller representou a liberdade como categoria da tragédia, a partir da dualidade entre a vontade e os instintos: a liberdade moral e a necessidade natural.

Segundo Machado (2006), a primeira reflexão filosófica do trágico nasce do encontro entre o dramaturgo Schiller com a filosofia de Kant, considerada como uma filosofia da liberdade. O primeiro ponto importante do pensamento desse dramaturgo sobre o trágico está na ideia de que a tragédia é a apresentação sensível do suprassensivel. Machado tem por hipótese de que o suprassensivel a que Schiller se refere "à subjetividade humana, ao homem, pensado como vontade livre ou liberdademoral, numa perspectiva muito mais moral do que propriamente metafisica." Schiller expressa esse conceito de super-sensivel para se referir ao que há de "grandioso no interior do homem, como resistência moral à paixão, ao afeto e ao sofrimento; uma força interior que lhe possibilita limitar os efeitos da natureza." (MACHADO, 2006, p.55). 
Ainda nesse capítulo, Machado esclarece que o suprassensivel - a liberdade - é representado através do sofrimento dos personagens, que chega à apresentação de uma liberdade moral. Ele esclarece:

A apresentação do sofrimento não é, portanto, o objetivo da tragédia; é um meio a serviço de seu fim, que é a apresentação do supra-sensivel. Ou, mais precisamente, a liberdade do homem, o poder moral, seu aspecto supra-sensivel, se manifesta na resistência ao sofrimento, no fato de suportá-lo, sentindo-o plenamente. [...] A natureza supra-sensivel do homem, é a resistência moral ao sofrimento ou aos afetos, às paixões, que a tragédia moderna apresenta e representa. Só conhecemos o supra-sensivel pela resistência que ele manifesta à violência dos sentimentos. O aspecto sensivel do homem tem de sofrer intensamente para que o seu aspecto racional possa manifestar sua independência [...] quanto à dor, o sofrimento, é violento - pois na base da experiência trágica apresentada pela tragédia se encontra o desprazer, mais gloriosa é a manifestação da autonomia moral do homem. (MACHADO, 2006, p.56).

Observa-se, portanto, mediante a consideração de Serra e de Machado que o trágico é um dos assuntos filosóficos que tem merecido atenção especial, não só no que concerne à arte, mas também no que diz respeito a eventos da vida humana em geral. Alguns dos estudiosos, dedicados à questão, pautam-se no conceito aristotélico de tragédia, isto é, imitação de acontecimentos que provocam piedade e terror e que ocasionam a catarse ou a purificação de eventos inesperados que amedrontam o homem.

Para discorrer sobre o trágico, Serra (2006) retoma o conceito de tragédia, afirmando-o ser dinâmico, uma vez que vai se alterando conforme a época. Com isso, consolida-se uma das afirmações feitas neste artigo logo em seu início, quando se propunha o exame diacrônico do conceito, assegurando a inviabilidade de uma noção única que perdurasse ou que se mantivesse sem alteração de sentido desde os gregos até os nossos dias. Acrescente-se, portanto, que as categorias trágicas se alteram conforme a situação ou problema em que se instaura o trágico. Nesse intento, Serra (2006) expõe suas ideias conceituais com muita clareza acerca das noções pelas quais o trágico se expressa, dizendo:

Entendo por "categorias trágicas" as diversas noções mediante as quais o trágico se expressa, ou, por outras palavras, os modos mais genéricos de dizer o trágico. Aceitando que a tragédia se constitui como acção, envolvendo uma específica inteligência do real [...] (SERRA, 2006, p.191).

Como se observou antes, as categorias do trágico podem ser distintas e autônomas entre si. Isso porque apresentam diferentes pontos de vista do trágico e, conforme Serra, dependem da interpretação que o tragediógrafo quer expressar em seu texto (SERRA, 2006, p.192). Segundo o autor, pode-se considerar como categorias do trágico: a culpa, a ânsia de conhecimento, o erro (hamartia), a desmedida (hybris) e outras que vão surgindo conforme a atuação do homem no mundo.

Conjectura-se que os heróis gregos estavam aprisionados aos seus destinos. Nisso diferem-se dos heróis considerados modernos que, normalmente, não aceitam os seus infortúnios, visto que granjeiam a esperança de que o futuro será melhor que 
o presente, que seja possivel de certa forma administrar o destino tanto quanto possivel.

\section{Considerações finais}

Como vimos o sentido da palavra tragédia foi sendo alterado com o passar dos séculos. O que outrora se destinava a celebrações a Dioniso deu lugar ao drama, entendido aqui, modernamente, como situação de alguma forma terrivel, frequentemente fúnebre, de que emerge um enlutado sentimento de perda e de dor. Depreendemos que, tanto a tragédia clássica como a moderna (romances, filmes e outros) ambas pertencem a gêneros literários "recheados" de personagens que enriquecem a narrativa por representarem dor, medo, sofrimento e outros sentimentos que propiciam a reflexão sobre a existência humana.

Na tragédia grega, o destino (moira) é esperado, pois é imposto pelos deuses. À exemplo de Antígona, o individuo aceita o que virá, assumindo seu destino. Em contrapartida nos romances modernos, o termo tragédia está mesmo ligado às concepções que dele temos ao usá-lo como infortúnios, impasses do dia a dia. Contudo, as semelhanças entre as narrativas modernas e a tragédia grega são inegáveis: ambas pautam-se em conflitos, embates, dilemas, sofrimento e muita dor reservados pelo desfecho de acontecimentos vários; alguns estabelecidos por vaticínios que, dentre os significados no dicionário usual da Língua Portuguesa consta como profecia e, mais, oráculo, palavra tão cara aos desígnios dos heróis gregos.

Os incidentes que, hoje, nomeamos como tragédia, ora se aproximam ora se distanciam do trágico grego, no sentido de que, no itinerário da vida dos personagens, cada incidente trágico vem prescrito pela hybris ou transgressão. Conforme o relato da narrativa é possivel que em muitas situações sejam desrespeitados os direitos humanos.

São situações em que o trágico, representado pela imagem do bode - animal que simboliza a expiação, ou ainda purificação, reconhecido na expressão "bode expiatório", tão cara aos nossos dias -, deixa transparecer elementos que nos remetem aos tempos helênicos. Graças ao texto literário, construído pela imaginação criadora do poeta, os fatos narrados evidenciam a condição humana e que se não aconteceram de tal forma, esses fatos ou semelhantes tragédias poderiam ter acontecido em quaisquer momentos da vida do homem.

\section{Referências}

ABBAGNANO, Nicola. Dicionário de Filosofia. Tradução de Alfredo Bosi. 2a ed. São Paulo: Martins Fontes, 1998.

ARISTÓTELES, Poética. Tradução de Eudoro de Souza. $2^{\mathrm{a}}$ ed. São Paulo: Ars Poética, 1993. Livro IV.

Física. Tradução de Alberto Barnabé Pajares. Madrid: Editorial Gredos, 1995. 


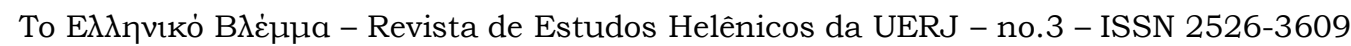

Alexandra Marla Marques da Rocha - UniRitter

BERTHOLD, Margot. História Mundial do Teatro. Tradução de Maria Paula V. Zurawski. 3. ed. São Paulo: Perspectiva, 2006.

BRECHT, Bertolt. Poemas de Svendborg. IN: WILLIAMS, Raymond. Tragédia Moderna. Tradução de Betina Bischof. São Paulo: Cosaf \& Naify, 2002. p. 247-264.

CHEVALIER, Jean. Dicionário de Simbolos (mitos, sonhos, costumes, gestos, formas, figuras, cores, números). Alain Gheerbrant com a colaboração de André Barbault... [et.al.]; coordenação Carlos Sussekind; tradução Vera da Costa e Silva [et.al] ; 20. ed. Rio de Janeiro: José Olympio, 2006.

ÉSQUILO, 525-456 a.C. Oréstia: Agamêmnon, Coéforas, Eumênides. Tradução Mário da Gama Kury. Rio de Janeiro: Jorge Zahar, 1991.

EURÍPEDES, 480-406 a.C. Medeia. Tradução Trajano Vieira. São Paulo: Editora 34, 2010.

GASSNER, John. Mestres do Teatro. Tradução de Alberto Guzik. São Paulo: Perspectiva, 1974.

JAEGER, Werner Wilhelm. Paidéia: A formação do homem grego. Tradução de Arthur Parreira: [adaptação do texto para edição brasileira Monica Stahel; revisão do texto grego Gilson César Cardoso de Souza]. 4. ed. São Paulo: Martins Fontes, 2001.

LESKY, Albin. A Tragédia Grega. Tradução de J. Guinsburg [et.al]. 2. ed. São Paulo: Perspectiva, 1990.

MACHADO, Roberto. O Nascimento do Trágico de Schiller a Nietzsche. Rio de Janeiro: Jorge Zahar, 2006.

MOISES, Massaud. Dicionário de Termos Literários. São Paulo: Cultrix, 1974.

ROMILlY, Jacqueline de. A Tragédia Grega. 2. ed. Coimbra: Edições 70, 1997.

ROSENFIELD, Kathrin Holzermayer. Desenveredando Rosa: a obra de J.G. Rosa \& outros ensaios rosianos. Rio de Janeiro: Topbooks, 2006.

SÊNECA (L.A. 4 a.C. - 64) Sobre a Providência Divina e Sobre a Providência do Sábio. Tradução de Ricardo da Cunha Lima. São Paulo: Nova Alexandria, 2000.

SERRA, José Pedro. Pensar o trágico: Categorias da tragédia grega. Lisboa: Fundação Calouste Gulbenkian, 2006.

SÓFOCLES (496 a.C - 406 a.C) Antigona. Tradução de Donaldo Schiller. Porto Alegre: L\&PM, 1999.

. Édipo Rei. Tradução de Paulo Neves. Porto Alegre: L\&PM, 1998.

SOUZA, Osvaldo. História Geral. 10. ed. São Paulo: Ática, 1974.

WEIR, William. 50 Batalhas que mudaram o mundo: os conflitos que mais influenciam o curso da história. Tradução de Roger Maioli dos Santos. 3. ed. São Paulo: M. Books, 2010. 


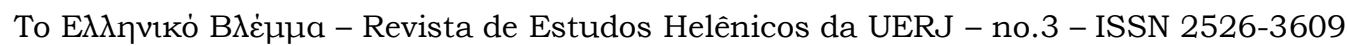
Alexandra Marla Marques da Rocha - UniRitter

WILliAMS, Raymond. Tragédia Moderna. Tradução de Betina Bischof. São Paulo: Cosaf \& Naify, 2002. 